\title{
The Role of Public Administration in Preventing Corruption of State Officials
}

\author{
Vicky Zaynul Firmansyah ${ }^{1 *}$ (D) Firdaus Syam² \\ 1,2Faculty of Social and Political Sciences, Universitas Nasional \\ ${ }^{*}$ Correspondence : vickyzaynulfnc01@gmail.com
}

\section{ARTICLE INFO}

\section{Article History}

Submited; June 2, 2021

Revised; June 11, 2021

Accepted; SJune 21, 2021

Available online: 08 July 2021

\section{Keyword}

Role

Public Administration

Corruption

\begin{abstract}
The main problem with the Indonesian government is the behavior of corrupt acts that harm the nation and state. This research is shown to prevent corrupt behavior by applying the principles of public administration in state officials. The research method used, namely this type of quantitative research is comparative experimental. There are various policies pursued by the government to prevent corrupt behavior, namely the application of public administration principles in state officials, ethical development and bureaucratic governance through good governance development, enforcement and application of public administration law, public awareness and participation, efforts to improve the system. more effective and efficient public services, and the establishment of independent institutions to prevent corruption. However, in this study, it was found that there were irregularities in the efforts to strengthen the KPK institution by reconducting a national insight test on employees, which led to irregularities in weakening the KPK due to the dismissal of competent employees.
\end{abstract}

\section{INTRODUCTION}

Indonesia is a multicultural unitary country, has many cultures, characteristics, customs and people who are different from one another. Indonesia is a state of law. Indonesia is a legal state that has independent characteristics, which means that independence can be seen from the application of the concept or pattern of the rule of law that it adheres to. According to the definition above, in a multicultural country there are many problems in the government, both in the political and administrative fields. Things that are often encountered are problems related to government and public service administration bureaucracy, such as acts of corruption committed by state officials. Because with that difference where everyone has different thoughts and interests, so we need a system and also regulations in accordance with the meaning of the rule of law.

In a government administration, problems must be found, both from the central government, state institutions to regional governments. One of the problems that often occurs in Indonesia is corruption. Corruption is an action or behavior that is considered deviant and endangers society and the state. The phenomenon of corruption has caused public distrust of the law and the criminal justice system and it is feared that it can lead to the dysfunctionalization of criminal law (Klitgard, 2001). The definition of the rule of law feels just 
a slogan or symbol, which is defeated by the power or political interests of the rulers. Corruption is an extraordinary crime, because its impact is not only detrimental to the country's finances or economy but also hampers national development. The phenomenon of the widespread disclosure and prosecution of perpetrators of corruption that occurs shows a tendency for deviations to continue to increase, even though seriousness in eradicating corruption has been carried out since 1960. weak so that corruption often occurs in every government.

Corruption is one of the biggest problems the Indonesian nation is currently facing. Corruption acts that occur in government agencies as public administration administrators have a negative impact on society and the state. The phenomenon of rampant disclosure and prosecution of perpetrators of corruption that has occurred recently shows a tendency for irregularities to continue to increase and become uncontrollable. In addition, public administration also includes all human activities related to the regulation of human resources and natural resources needed to achieve state goals. The large number of state agencies, both executive, legislative, and government institutions whose members are entangled in corruption cases, proves the lack of understanding of the meaning of duties, authorities, and responsibilities in carrying out public administration functions.

As organizers of public administration, state officials must firmly hold the principles of public administration services in their duties and responsibilities. However, what happens is that these principles are ignored and creates gaps for acts of corruption. From this discussion, it means that acts of corruption are closely related to state/public administration, because corruption is an act that harms many people in a country. Weak state administration will facilitate acts of corruption or bribery and it will have a long impact that involves and is detrimental to the state. So it is necessary to take firm action against the problem of corruption, improvement of a good administrative system and also clear laws. After understanding the description of the background, it can be identified a common thread or problem that must be solved, namely: How the role of public administration science can reduce the behavior of corrupt state officials.

\section{RESEARCH METHODS}

This type of quantitative research with research methods taken is comparative experimental, namely to prove whether public administration has an influence or not in preventing acts of corruption and the relationship between the principles of public administration in preventing acts of corruption. Data collection techniques through interviews, observation, and comparing the results of previous studies (Creswell et al., 2007). The data sources used by researchers are primary and secondary data sources. The primary data needed include interviews and observations of understanding and implementation of the principles of public administration on state officials, namely leaders and civil servants (PNS) from sub-district government institutions, ministries and the DPR. Secondary Data The data is obtained from the results of previous research, survey results, and performance reports or reports on cases/news of corruption acts such as those from the KPK agency website.

\section{RESULTS AND DISCUSSION \\ Definition of Corruption}

Corruption is behavior that deviates from the official duties of a state position because of status gains or that involves personal or individual, close family, own group (Klitgard, 2001). Etymologically the word corruption comes from the Latin coruptio or corruptus or also comes from the word cossumpere. That Latin language descended into many European languages such as English, corruption, corrupt; France, corruption; and the Dutch corruptie. Thus it can be concluded that the word corruption in Indonesian comes from the Dutch language. In the sense of the word, corruption is an act of misappropriation or embezzlement of state or company money for personal or other people's interests. So that corruption is an act that 
deviates from the rules and results in harm to the state and society, such as embezzlement of money, receipt of bribes and so on.

Corruption is basically an anti-social act, contrary to morals and the rule of law. The impact if these actions are not prevented or addressed, namely the public relations system will become inharmonious, will proceed towards a system of individualism, bribery, loss of trust in the government and the like. In time, the mentality of an individual, group or part of our nation's society will be colored by deceit and lust to benefit oneself or the group which is usually achieved by justifying all kinds of means Acts of corruption also arise from the existence of conditions or systems that provide opportunities or possibilities for certain people or groups to commit corruption. The rise of corruption as an extraordinary crime requires extraordinary efforts (extra ordinary measures) to prevent and eradicate it (Satria, 2020).

Corruption behavior can be defined into 3 categories, namely definitions centered on public office, market conditions or conditions, and public interest. Examples of corrupt activities are taking or using state money for personal interests, bribery activities, embezzlement in office, extortion, fraudulent acts, conflicts of interest in procurement and policy, and gratuities. Corruption always brings negative consequences to the process of democratization and development, because corruption has delegitimized and reduced public trust in the political process through money politics. Corruption has also distorted decision-making in public policies, lacks public accountability, and the principle of the rule of law. Epistemologically, the type of corruption that is often found in the government environment, whether it is at the center or the region is corruption related to public services (Satria, 2020). This relates to the bureaucratic environment and public services, such as in the field of licensing or business permits. On the other hand, corruption also causes various development projects and public facilities to be of low quality and not in accordance with proper needs, thus hampering longterm sustainable development (Joniarta, 2018).

\section{Definition of Public Administration in Good Governance}

Public administration or originally referred to as state administration is a system or science that is applied to support the administration of Indonesian government in realizing the ideals and goals of the nation and state. In its development since the 20th century, public administration is defined broadly which includes all activities of all state institutions, both legislative, judicial and so on. More broadly, public administration can be interpreted as human actions that work together within the scope of government bureaucratic institutions, the business world and or the community, which aims to provide services and good governance to the community (Sinaga, 2007).

The application of the principles of good governance is very important in the implementation of public services to improve the performance of the state apparatus (Maryam, 2016). Because the government runs and builds the principles of good governance to increase the potential for changes in the government bureaucracy in order to realize good public services. This is an effort by the government to improve the quality of public services, which are considered by the public to be slow, unprofessional, and expensive. The definition of good governance is explained in Government Regulation No. 101 of 2000, which formulates the meaning of good governance as follows: "Government that develops and applies the principles of professionalism, accountability, transparency, excellent service, democracy, efficiency, effectiveness, rule of law and can be accepted by the public. whole society". Thus, good governance means the activities of a government institution that are carried out based on the interests of the people and applicable norms to realize the ideals of the state in which power is exercised by the people who are regulated at various levels of state government related to socio-cultural, political, and economic resources. and economy (Maryam, 2016).

Public Administration is a science that studies the implementation of government policies, public services, and efforts to implement those policies through government agencies or organizations to achieve state goals. This is where public administration brings the principles of strengthening public accountability, enforcement of the law, understanding of duties, attitudes, and responsibilities, transparency and supervision. Another problem arises 
from the government's role in carrying out state administration activities. The phenomenon of public service by the government bureaucracy is full of problems, for example long-winded service procedures, uncertainty of time and price which causes services to be difficult to reach fairly by the community (Maryam, 2016). This creates loss, distrust, and public suspicion of the government. The absence of openness and uncertainty, and sometimes people get unfair or unappreciated behavior by public officials in getting services experienced by the community, this indicates that the principles of good governance are still not used properly in the implementation of public service activities in Indonesia.

The mechanism for the principle of public accountability is also not only intended to measure performance, but can also monitor the behavior of public officials in order to comply with ethics and applicable legal rules (Kurniawan, 2009). So that from the problems that occur in the field that arise from the process of providing public services to the community, it is important that in running the government system it is necessary to apply the principles of good governance as a form of implementing public administration. This is an effort to improve the quality of sustainable public service delivery to realize excellent public services, because public service is the main function of government that is best provided by public officials.

Good governance is a criterion for a good and successful state condition in development, it is even used as a criterion for obtaining optimal assistance capabilities and good governance is considered a standard term for public organizations only in the sense of government. According to the state administration agency in (Diana, 2015) suggests the meaning of good governance means Values that uphold the wishes/will of the people and values that can increase the ability of the people in achieving the (national) goals of independence, sustainable development and social justice. Functional aspects of government are effective and efficient in carrying out their duties to achieve these goals. To form a good order of life for the nation and state, it all depends on the system of government that is adopted, Indonesia currently adheres to a people's democratic government system where in decisionmaking and policy-making everything is very dependent on the voice of the people. However, a system that does not work well makes it difficult for this country to advance to compete with other countries. as for the principles of good governance in government regulation no. 101 of 2000, namely:

a. Professionalism, improving moral abilities and having responsibility for the work of government administrators so that they are able to provide easy, fast, precise services at affordable costs.

b. Accountability, increasing the accountability of decision makers in all fields concerning the interests of the community.

c. Transparency, creating mutual trust between the government and the community through the provision of information and ensuring convenience in the community through the provision of information and ensuring the ease of obtaining accurate and adequate information.

d. Excellent service, the implementation of public services that include good procedures, clarity of rates, certainty of time, ease of access, completeness of facilities and infrastructure as well as friendly and disciplined services.

e. Democracy and participation, encourage every citizen to exercise the right to express opinions in the decision-making process, which concerns the interests of the community, either directly or indirectly.

f. Efficiency and Effectiveness, ensuring the implementation of services to the community by using available natural resources in an optimal and responsible manner.

g. The rule of law and can be accepted by the whole community, to realize the existence of fair law enforcement for all parties without exception, upholding human rights and paying attention to the values that live in society.

The basic principles of good governance provide and have an important influence in creating good and ideal governance conditions. To implement good governance in governance in Indonesia, the principles of good governance should be used and used as guidelines in various government institutions. By implementing the principles of good 
governance, we must work together, as in the three pillars, namely the government, corporations, and civil society should take care of each other, support each other and actively participate in the administration of government that is being carried out. If these principles are implemented, they will reduce the risk of corruption in Indonesia. This shows how clear and important the role of public administration is in eradicating corruption. Public administration, which includes the bureaucracy, is an important organization that regulates governance, starting from the allocation of human resources to budget allocations. An effective bureaucracy is a bureaucracy that is free of corruption, which is free from various kinds of irregularities to benefit oneself and the group. Corruption appears as a form of not implementing a good government system. Because a good government system is a government system that is in accordance with applicable principles (Fatkhuri, 2018).

\section{Factors Causing Corruption}

To eradicate corruption, we need to look again at the factors that cause corruption and eliminate these factors. The factors that cause corruption as explained on the previous page are (Kartayasa, 2017) :

a. Weak law enforcement; This means that the law in Indonesia must be strengthened not only from its regulations, but also from its maximum implementation. Weak laws and mere names make corrupt actors and officials prone to corruption arbitrarily and not deterred from committing acts of corruption.

b. Pessimistic attitude towards corruption; of course everyone thinks that corruption is a bad behavior that must be avoided. But sometimes we are too busy to think so, to ignore that the demands that come from us are the ones that cause corruption. For example, when we take care of something in a government agency and everything has a predetermined deadline. But because we are impatient and want to hurry, we also persuade government officials or bureaucratic officials to immediately solve our needs, we give them wages other than the salary they should receive.

c. Lack of exemplary leadership; This is human nature that becomes arbitrary if given the responsibility as a leader. Whereas as a leader we should have a sense of responsibility and high integrity to shape the organization we lead to be better. A leader should have more awareness that he is a role model who will set an example for many people.

d. Weak moral integrity; Morals make people do their jobs seriously, morals make people understand, and morals make people act according to their nature as humans. People who commit corruption find it difficult to distinguish between needs and wants, and they forget the real responsibilities of the work they carry out. This shows that morality is something that is very important for everyone to have so that he or she has self-awareness and avoids corruption.

\section{Salary That Doesn't Match The Job}

This triggers acts of corruption because someone who feels that the wages they get are not in accordance with the work they do, will be moved to commit corruption. He feels that corruption is something that is natural because the salary he receives for his work is also not appropriate. These five factors can be overcome by good state administration, management of the business world and society as well as state apparatuses that heed the principles of public administration in good governance. The executive, legislative and judicial institutions in public administration play an important role in overcoming these factors because from the central government to local government, they are part of public administration. In the implementation of public administration, it is divided into executive, legislative, and judicial institutions. Where the executive body is held by the president and his deputy and ministers, and there are also regional heads such as regents, mayors, and governors. The executive body is in charge of administering and implementing laws made together with the legislature in order to achieve state goals. 
The legislative body consists of the MPR, DPR, DPD, and DPRD, where the main functions of the legislative body, especially the DPR are as a drafting or law-making agency, as a budget planning agency (APBD), and also as a supervisory or control function. Judicial institutions or judicial institutions to maintain laws, regulations and other legal provisions so that they are truly obeyed, namely by imposing sanctions on every violation of law/laws and giving fair decisions on civil disputes that are brought to court to decide. In state/public administration, the role of all institutions, both central and local, must play an active role in eradicating corrupt practices. Because with good administration, the administration of the state will run according to its objectives and all activities are monitored, recorded and proven so that corrupt behavior can be reduced.

\section{The Role of Public Administration in Preventing Corruption Behavior}

1. Corruption Eradication in Good Governance Review

The principle of public administration in good governance or the general principle of good governance is a condition when the state is already in a state of chaos in the political, economic, social, legal, and administrative fields, including the mechanisms or processes and institutions that handle them. Many elements of the principles of good governance have been accepted by the community, the most important of which are carefulness, security, reasonableness, equality, and balance. If it is related to the state as a whole, the principle of good governance is a principle that prioritizes the balance of relations between the community and the state and the state and individuals. This means that every public policy inevitably has to involve various parties and sectors, including the government, society and the private sector with clear rules of the game. Thus, the implementation of good governance in Indonesia is expected to be able to create a democratic political format, and give birth to alternative development models that are able to mobilize community participation in all areas of life.

When viewed from the current condition of Indonesia, which has no balance, then the principle of good governance is not a solution to protect and cleanse this country from the issues of corruption, collusion and nepotism. Because corruption has existed in our midst since the beginning, humans began to form organizations and corruption is part of collective activities. However, this does not mean that we should be indifferent, because corruption destroys economic life and the moral foundation of the way of life. Efforts to realize good governance in Indonesia are a priority in order to create a more prosperous society, nation and state, far from corruption, collusion, and nepotism, because in reality people are still far from living decently, corruption is still rampant. But the struggle to create a clean government must not stop.

In Indonesia, we can see that the opportunities for corruption are so great, the bureaucracy is so long, the salaries of civil servants are small, there is no public complaint system and almost all political parties are looking for money to grow their parties. The concept of good governance as a reliable approach will not guarantee a reduction in corrupt practices, if government officials at the center do not set a good example for regional officials. This is rationally justified because of the excesses of central domination as a center of power and money. On the other hand, there are also concerns with the delegation of authority from some of the central tasks to the regions, so it is certain that corruption at the center will move to the regions. However, this may be prevented by developing a system of checks and balances, both internally and externally through joint efforts to empower the community to build a sense of ownership and interest in the progress and decline of their respective regions.

Corruption is caused because there is so much monopoly, power, and discretion. For this reason, to build good governance, it must involve and invite all components of stakeholders, both within the bureaucracy and in the community. Good governance is a government that is close to the community and in providing services must be in accordance with the needs of the community (Maryam, 2016). The description of the establishment of good bureaucratic governance is characterized by the implementation of good public 
services, this is in line with the essence of decentralization and regional autonomy policies aimed at providing flexibility to regions to regulate and manage local communities, and improve public services. So that with the establishment of good and ideal bureaucratic governance conditions with the application of good governance principles, it will indirectly cut off opportunities for acts of corruption and suppress such behavior by emphasizing the existence of sanctions, both legal sanctions and clear norm sanctions. The involvement of all parties, especially in the three pillars of good governance, namely the state/government and its apparatus as regulators, the business world or the private sector as market players, and the community as users of products from the business world, is very much needed in realizing a government condition that is free from corrupt practices.

\section{Eradication of Corruption in State/Public Administrative Law Review Administrasi}

In the study of Public Administration, there is material that discusses State Administrative Law. State administrative law is the law that regulates government actions, both state institutions and state officials and regulates the relationship between government-citizens or relations between government institutions. State administrative law or governance law has the function of rules and regulations that regulate the position, authority and actions of state institutions, determine their place in the state, determine the position of citizens, and legal regulations that regulate the actions of these government institutions. So that State Administrative Law regulates the position, duties, functions, responsibilities, rights, and obligations of institutions and government officials and regulates relations between state institutions and also with the community.

Implementation of the current legal politics of government, in the implementation of public services, the spirit that must be instilled in the implementing apparatus is the spirit of providing the best for service users, which must be understood as an attitude that arises from an awareness of these values (Nuriyanto, 2015). The same thing is also discussed in the State Administrative Law which is one of the references in efforts to prevent corrupt behavior that occurs in government agencies, especially in the administration and public services. Because State Administrative Law provides the basis for the formation of good governance conditions based on legal provisions. The application of state administrative law that is carried out and implemented properly will have a positive impact and change towards progress in government pawns. The strategy of eradicating corruption in the perspective of state/public administration law includes several areas of change (Adji, 2006), namely as follows:

a. Leadership Over Good Governance; For the elected legislature, it is the main pillar of a national integrity system based on democratic accountability. His task in simple language is to realize people's sovereignty through elected representatives for the public interest, to ensure that executive actions can be accounted for. Similarly, the government gets legitimacy after getting a mandate from the people (Adji, 2006).

b. Government Organization Improvement; In addition to making changes to specific programs, attention is needed to prevent corruption through changes to the organizational structure of government. This requires a change in the way the government carries out its day-to-day duties. By eliminating the impression of a bad government and becoming a conversation between the public and the government as private land, disseminating information to citizens about their right to receive services from the government, publishing a handbook for civil servants that can be easily obtained and studied by citizens contractors who are in contact with the relevant government agency, and eliminate one-on-one contact by including random elements, for example, rotation of staff members from time to time and giving appreciation or appreciation to honest and competent employees. Another thing is the improvement of the administration administration system by developing an excellent, effective and efficient public service system. So that citizens who have an interest in them can no longer know in advance which official he has to deal with. 
c. Law enforcement; Efforts to eradicate corruption through law enforcement must prioritize all parties, fair and clear laws, not only making regulations but regulations only weakening the criminal law of corruption itself. The law must be clear, how an act of corruption can be punished and how sanctions can be imposed on people who commit corruption, sanctions are firm and clear. So far, the law for criminal acts of corruption in Indonesia seems to be just a game of the political elite. Sanctions that are not clear and too light, create no deterrent effect or fear when committing acts of corruption. The corruptors seem to be protected by the law. For this reason, it is necessary to have a firm, clear and legal law without any interest in power, namely with a new law. With the issuance of this law, it is hoped that state administrators will be able to carry out their functions and duties seriously and responsibly. Enforcing the law is important, but a strategy that focuses solely on law enforcement will almost certainly fail and will most likely not be able to create an ethical environment that rejects corrupt behavior, therefore public participation is very much needed in eradicating corruption in the public sector.

d. Community Awareness and Participation; What is no less important is the courage and determination of the entire state apparatus and society to fight corruption. There are still many prosecutors who are afraid to carry out prosecutions because corruption involves important and powerful people. Courage must be grown together with increasing public awareness of the law. In culture and behavior, psychologically we know the culture of shame (shame culture) and wrong culture (guilt). Shame culture is a pattern of behavior that shows "losing face" or feeling embarrassed when someone makes a mistake in front of others. Meanwhile, wrong culture can be seen from what is felt in a person's mind. Thus, the culture of shame only causes guilt if someone commits a crime and is known by other parties, whether it is friends, superiors or financial supervisors, but a wrong culture can be seen from the sense of guilt if someone commits a moral deviance even though others do not know. So the most powerful bulwark to prevent someone from acts of corruption is wrong culture.

e. Establishment and Strengthening of Corruption Prevention Agencies; Countries that are really trying to eradicate corruption need to establish new institutions or strengthen existing institutions and can carry out specific functions in anti-corruption efforts. Although many institutional models are available, whatever model is used, the institution must be equipped with sufficient human resources. Otherwise, the long list of ineffective anti-corruption agencies will continue to grow. Such as strengthening the KPK institution, by making it an independent institution. In addition to these matters, the press also plays an important role in efforts to eradicate corruption. Press activities must be encouraged without excessive attitude on the part of the government. The press that is needed is a press that is able to represent the aspirations of the people, find various forms of administrative irregularities, and is able to become a means of reciprocal communication between the people and the government. The press should not only be a control tool for abuses in the development program because it is impossible for development supervision to be fully delegated to structural and functional supervisory units.

\section{Paradigm of KPK Strengthening Issues}

Strengthening the KPK as an independent institution to prevent and monitor corruption in Indonesia is an effort that must be done immediately as an effort to prevent corruption in Indonesia. However, in reality, the issue of weakening KPK employees has emerged with the return of conducting national insight tests on KPK employees. As quoted in the online news, Liputan 6 stated that "they fired 51 of their employees from a total of 75 people who did not pass the national insight test (TWK) as a condition for changing their status to become state civil servants (ASN)". The reason is that if the government wants to make KPK employees into ASN, it should not be again to conduct a national insight test against KPK employees who have been tested and have been tested before working at the KPK. This gives rise to various 
paradigms of the issue of weakening the KPK by dismissing KPK employees who are competent and responsible for their duties, because the national insight test actually does not affect the duties and performance of KPK employees.

As the decision of the Constitutional Court has emphasized in the judicial review of the KPK Law, the process of transferring employee status must not harm the rights of KPK employees. However, the KPK leaders did not comply with the decision, which ultimately fired employees who did not pass. If the government and KPK leaders want to transfer employee status, it is better to conduct regular assessments of their employees rather than conducting incidental tests such as the national insight test. The work assessment program should not focus on just one test, but rather on analyzing employee track records regarding their duties and responsibilities during work, because TWK cannot be used as a benchmark for the appointment of KPK employees to become ASN. The implementation of this test indirectly casts doubt on the quality of KPK employees. Where employees who do not qualify, actually have a long track record in efforts to eradicate corruption. If many employees are laid off in the middle of handling corruption cases, it will slow down the process of handling the case.

Irregularities emerged from the national insight test process, such as the sudden notification received by the employee regarding the national insight test, there were questions that had no basis and were not relevant to the duties and obligations of KPK employees. The results of the provision of the national insight test should not be the basis and benchmark for the dismissal of KPK employees, because the test cannot represent and state that the employee is incompetent. If you want to strengthen KPK employees, what you can do is provide training and assessment programs to assess workers as a whole regarding their track record and achievements during work. So this can reduce credibility and create a lack of public trust in the performance of the KPK. This raises the question that there are efforts to weaken the KPK by firing competent employees. The results of the national insight test should be used as the basis for screening employees to provide training and re-education on the basics of nationality, not even firing and dismissing employees without clarity and certainty.

\section{CONCLUSION}

Indonesia is one of the largest countries and the largest multicultural country in the world which has natural wealth and various tribes, cultures and customs, but the Indonesian people are not prosperous, this is caused by several factors, one of which is corruption. Corruption is the biggest problem and has a bad impact on the progress of the nation. Corruption is a deviation from a person's rights and obligations from what he should do. Corruption has a very negative impact on individuals, groups, governments, communities, and countries. Meanwhile, public administration is a process of administering the state in achieving its life goals in the state. Corruption often occurs in bureaucratic government in the field of administration and public services, this is influenced by the lack of application of the principles of public administration and the weak development of good governance, the lack of a clear legal basis, and the lack of community participation.

The role of public administration to eradicate corruption is very important because state/public administration covers all issues that exist within the country, including corruption. There are various policies and rules as well as steps that can be applied by the government to prevent corrupt behavior of state officials, namely the application of the principles of public administration to state officials by providing education and training as well as socializing the impact of corruption, strengthening accountability, professionalism, transparency in administration, development and improvement of the service system that is excellent, effective and efficient in administration, implementation of democracy and involving community participation, and the rule of law, development of ethics and governance of the government bureaucratic system with the development of good governance, enforcement and application of clear administrative law by giving strict sanctions against suspects of corrupt behavior, giving appreciation and appreciation to honest and competent employees, as well as strengthening institutions to prevent corruption. 
Strengthening the Corruption Eradication Commission (KPK) is actually a must that must be carried out immediately as an effort to eradicate corruption. But in reality there are various interests of the authorities to weaken the KPK. The issue arose from the dismissal of KPK employees because they did not pass the national insight test which became the determinant of the dismissal of KPK employees. Supposedly if the leader wants to evaluate the performance of his employees, it is better to conduct a comprehensive assessment program of the employee's performance during work instead of making the results of the national insight test to fire employees. It is better if the test is used to screen employees who later do not pass the training and provide national insight. This reduces the credibility of the KPK as an independent institution to eradicate corruption and creates public distrust of the KPK.

Indonesia is one of the countries with the largest corruption cases, eradication of corruption must be done immediately. For this reason, public administration must be carried out and carried out as well as possible without taking sides in one direction or being mixed with various political or power interests. The state administration must run in a neutral manner and must not participate in cheating to commit corruption. In addition, the government as an apparatus that carries out the function of administering public administration should be more law-abiding and apply the principles of public accountability, openness, fairness, and prioritize the public interest above personal interests so that it can set a good example for the community and make administration and service arrangements. corruption-free public.

\section{REFERENCE}

Adji, I. S. (2006). Korupsi, kebijakan aparatur negara, dan hukum pidana. Diadit Media.

Creswell, J. W., Hanson, W. E., Clark Plano, V. L., \& Morales, A. (2007). Qualitative research designs: Selection and implementation. The counseling psychologist, 35(2), 236-264.

Diana, R. (2015). Sumber Daya Manusia Dan Produktivitas Kerja. Jurnal Istinbath XIV, (15). https://core.ac.uk/download/pdf/267946537.pdf

Fatkhuri, F. (2018). Korupsi dalam birokrasi dan strategi pencegahannya. Jurnal IImiah Manajemen Publik dan Kebijakan Sosial, 1(2), 65-76. https://doi.org/10.25139/jmnegara.v1i2.784

Fitria. (2012). Eksistensi Komisi Pemberantasan Korupsi (KPK) sebagai Lembaga Negara Penunjang dalam Sistem Ketatanegaraan Indonesia. Jurnal Nestor Magister Hukum, Vol. 2, No 2 (2012). Jakarta.

Joniarta, I. W. (2018). Banalitas Korupsi di Indonesia: Suatu Tinjauan Dari Perspektif $\begin{array}{llll}\text { Budaya. Jurnal Ilmiah Dinamika } & \text { Sosial, 2(1), }\end{array}$ https://doi.org/10.38043/jids.v2i1.358

Kartayasa, M. (2015). Korupsi \& Pembuktian Terbalik: Dari Perspektif Kebijakan Legilasi dan Hak Asasi Manusia. Kencana.

Klitgaard, R. (2001). Membasmi Korupsi. Jakarta : Yayasan Obor Indonesia.

Kurniawan, T. (2011). Peranan Akuntabilitas Publik dan Partisipasi Masyarakat dalam Pemberantasan Korupsi di Pemerintahan. BISNIS \& BIROKRASI: Jurnal IImu Administrasi dan Organisasi, 16(2). http://journal.ui.ac.id/index.php/ibb/article/viewArticle/612

Maryam, N. S. (2017). Mewujudkan good governance melalui pelayanan publik. JIPSI-Jurnal IImu Politik Dan Komunikasi UNIKOM, 6. https://repository.unikom.ac.id/51314/

Nuriyanto, N. (2015). Membangun Budaya Hukum Pelayanan Publik untuk Mewujudkan Kesejahteraan Rakyat. INTEGRITAS, 1(1), 15-36. http://eprints.uwp.ac.id/id/eprint/744/

Peraturan pemerintah No. 101 tahun 2000. Peraturan Pemerintah (PP) tentang Pendidikan Dan Pelatihan Jabatan Pegawai Negeri Sipil. LN. 2000 No. 198, TLN No. 4019, LL SETNEG : 12 HLM.

Satria, H. S. (2020). Kebijakan Kriminal Pencegahan Korupsi Pelayanan Publik. Integritas: Jurnal Antikorupsi, 6(2), 169-186. https://doi.org/10.32697/integritas.v6i2.660

Sinaga, O. (2007). Implementasi Sistem Administrasi Negara Indonesia dan Peranan Lembaga Negara dalam Membangun NKRI. Jurnal Administratur, 1(3). 